\title{
Save horseshoe crabs and coastal ecosystems
}

Article

Accepted Version

Yang, H., Thompson, J. R. and Flower, R. J. (2019) Save horseshoe crabs and coastal ecosystems. Science, 366 (6467). pp. 813-814. ISSN 1095-9203 doi:

https://doi.org/10.1126/science.aaz8654 Available at https://centaur.reading.ac.uk/87288/

It is advisable to refer to the publisher's version if you intend to cite from the work. See Guidance on citing.

To link to this article DOI: http://dx.doi.org/10.1126/science.aaz8654

Publisher: American Association for the Advancement of Science

All outputs in CentAUR are protected by Intellectual Property Rights law, including copyright law. Copyright and IPR is retained by the creators or other copyright holders. Terms and conditions for use of this material are defined in the End User Agreement.

\section{www.reading.ac.uk/centaur}

\section{CentAUR}

Central Archive at the University of Reading

Reading's research outputs online 


\section{Save horseshoe crabs and coastal ecosystems}

Chinese horseshoe crabs (Tachypleus tridentatus) are one of the oldest marine living fossils. Horseshoe crabs have existed for more than 445 million years (1) but populations of the Chinese species have plummeted in recent decades as a result of increasing biomedical demands, harvesting for human consumption, and habitat loss (2). Urgent action is needed to reverse population declines and protect coastal ecosystems.

Chinese horseshoe crabs play key roles in coastal ecosystems as benthic predators, prey, bioturbators, and hosts for epibionts (3). Their eggs are a major protein source for migratory shorebirds (4). However, discovery and commercialization of the Limulus Amoebocyte Lysate (LAL) test for bacterial endotoxin, which uses blood from horseshoe crabs, has driven population declines (5). More than 610,000 horseshoe crabs were harvested and nearly 80,000 killed for LAL production in 2012 alone (6). Adult horseshoe crabs are also a prized dish in many seafood restaurants. A survey in south China found that 132 of 155 restaurants offered horseshoe crabs (7). Climate change and associated ocean acidification, urbanization, land reclamation, and water pollution are exacerbating habitat loss, affecting horseshoe crabs' spawning activities and juvenile nurseries (8). Breeding pairs in Guangxi Province, the species' Chinese stronghold, declined from between 600,000 and 700,000 in the 1990s to 40,00020 years later (9). Declining horseshoe crab populations have implications for entire coastal ecosystems, especially shorebirds (4).

In March 2019, the International Union for Conservation of Nature (IUCN) listed the species as endangered (10). Urgent measures are needed to save horseshoe crabs. Research into animal-free LAL production is a priority (6). Management action should focus on protecting spawning and nursery habitats. Relatively few Chinese people are aware of the horseshoe crabs' plight. Public education is therefore needed, especially for younger generations (11). China's Belt and Road Initiative, including the New Maritime Silk Road, could further increase illegal cross-border animal trade, including horseshoe crab smuggling (12). More international collaboration will be indispensable for protecting this endangered species.

\section{Hong Yang ${ }^{1,2 *}$, Julian R. Thompson ${ }^{3}$, Roger J. Flower ${ }^{3}$}

${ }^{1}$ Chongqing Engineering Research Center for Remote Sensing Big Data Application, School of Geographical Sciences, Southwest University, Chongqing 400715, China. ${ }^{2}$ Department of Geography and Environmental Science, University of Reading, Reading RG6 6AB, UK. ²Department of Geography, University College London, London, WC1E 6BT, UK.

*Corresponding author. Email: hongyanghy@gmail.com

\section{REFERENCES AND NOTES}

1. D. Rudkin, G. Young, in Biology and Conservation of Horseshoe Crabs, J. Tanacredi, M. Botton, D. Smith, Eds. (Springer, New York, 2009), p. 25-44.

2. Y. Li, X. Xie, K. Y. Kwan, Wetland Sci. 16, 690 (2018) [in Chinese].

3. B. K. Kwan, H. K. Chan, S. G. Cheung, Aquat. Conserv. 28, 124 (2018).

4. C. P. McGowan et al., Ecosphere 2, 1 (2011).

5. J. Levin, H. D. Hochstein, T. J. Novitsky, in The American Horseshoe Crab, C. Shuster Jr, R. Barlow, H. Brockmann, Eds. (Harvard University Press, Cambridge, MA, 2003), p. 310-340.

6. G. Gauvry, in Changing Global Perspectives on Horseshoe Crab Biology, Conservation and Management, R. Carmichael, M. Botton, P. Shin, S. Cheung, Eds. (Springer International Publishing, Switzerland, 2015), p. 475-482.

7. Z. Weng et al., Chin. J. Zool. 47, 40 (2012) [in Chinese]. 
8. Q. Li, J. Biol. 27, 71 (2010) [in Chinese].

9. Q. Li, M. Hu, Mar. Environ. Sci. 30, 131 (2011) [in Chinese].

10. K. Laurie et al., "Tachypleus tridentatus," The IUCN Red List of Threatened Species (2019); www.iucnredlist.org/species/21309/149768986.

11. G. Kreamer, S. W. Kreamer, in Changing Global Perspectives on Horseshoe Crab Biology, Conservation and Management, R. Carmichael, M. Botton, P. Shin, S. Cheung, Eds. (Springer International Publishing, Switzerland, 2015), p. 557-574.

12. A. M. Lechner, F. K. S. Chan, A. Campos-Arceiz, Nat. Ecol. Evol. 2, 408 (2018). 